\title{
Development of Methodology of Storage System Management
}

\author{
Tatiana Gennadievna Shulzhenko ${ }^{1}$ \\ ${ }^{1}$ St. Petersburg State University of Economics (UNECON), St. Petersburg, Russian Federation \\ Correspondence: Tatiana Shulzhenko, St. Petersburg State University of Economics (UNECON), 21, Sadovaya \\ street, St. Petersburg, 191023, Russian Federation.
}

\author{
Received: March 11, 2015 Accepted: March 30, 2015 Online Published: May 22, 2015 \\ doi:10.5539/res.v7n9p120 URL: http://dx.doi.org/10.5539/res.v7n9p120
}

\begin{abstract}
This article represents definitions and describes the characteristics of logical and temporal structure of storage management according to the general laws from the perspective of understanding the methodology as the activity arrangement study, and administration in general as one of the types of practice activities.

Based on the study of the essential characteristics of storage systems, such as methodological principles of design and analysis of such systems, the goals and objectives of storage logistics for various administration levels are summarized and formulated. The choice of analytical tools for their solution depending on the level of logistics system development and maturity of logistics integration processes is justified.
\end{abstract}

Keywords: methodology of logistics, system approach, storage systems, storage and material handling, design and technology type of activity arrangement

\section{Introduction}

Warehousing, storage, and material handling have been traditionally included in the triad of functions (along with transportation and inventory), which directly determines the benefits of an integrated approach in logistics.

According to the estimates by various authors (Fugate, 2010; Hompel, 2003), the cost of implementing logistic functions related to the warehousing and storage of products in the supply chain, ranges from 23 to $37 \%$.

Taking the foregoing into consideration, it is important to pay special attention to the forming methodology of the storage system management.

From this perspective, it seems reasonable to use a common approach to the formation of the methodology developed by the authors (Novikov \& Novikov, 2007), according to which the methodology is considered as "the study of activity arrangement". Adaptation of this approach allows carrying out a number of the following important tasks:

a) To combine the most important modern aspects of requirements for storage system logistics management based on the concepts of "practice activities", "organization", "design and technology type of activity arrangement" on theoretical and methodological level;

b) To balance the requirements of the object and process approach to the management of such systems;

c) To regulate the existing elaborations in the study area (storage systems management), including determining the direction of the necessary development.

\section{Literature Review}

The question of the "storage system" concept as one of the main ones in the framework of the theoretical grounds for the storage logistics remains uncertain. From the perspective of conceptual framework of forming the basic logistics conceptual apparatus (Dybskaya et al., 2008), a "logistics system" is nothing but "a set of logistic network and administration system, formed by a company to implement its logistic strategy (tactics)", and, therefore, a "storage system" is justifiably considered as a broader concept. On the other hand, the results presented in the papers by many authors (e.g., (Dietrich, 2003; Dorodnikov \& Malashenko, 2001; Dybskaya, 2000; Dybskaya, 2005; Dybskaya, 2008; Dybskaya, 2009; Kireyev, 2009; Kuzmina, 2000; Kurganov, 2009; Misener, 2009; Misener \& Nikolaeva, 2006; Malikov, 2005; Mirotin \& Atayev, 2004; Pashkov \& Polyarin, 2003; Pustobaev, 2001; Savin, 2001; Taran, 2006; Emmett, 2007; Hompel, 2003) allow percepting the storage system as a system with dual nature: both as an independent logistics system and as a part of the logistics system of a 
higher level.

A similar view is shared by the authors (Grigoriev et al., 2006), considering storages in logistics as "the elements of physical distribution systems and at the same time as an independent system", which, in turn, allows creating two actual areas of research in storage logistics in the process of its methodology formation. The first direction is related to the study of the role and place of storage systems in the logistics system, i.e. higher level systems. The second one involves the formulation and solution of problems of storage business as an independent micro logistics system.

When addressing the former problem, there are two fundamentally important issues: first, the study of correlation of concepts of a "logistics system" and a "storage system"; second, the disclosure of the economic substance of storage systems as social and economic systems.

Let us discuss this issue in more detail. Based on the above-mentioned arguments, it is reasonable to assume that the storage system must meet the following requirements:

1) Have the characteristics and properties of the logistics system;

2) Be structurally described by a set of storage network and administration systems;

3) Correspond to the possibility of achieving the goals and objectives arising from the company's logistics strategy.

Summing up of the concept of logistics system, given by various authors see in (Table 1).

Despite the semantic diversity of the provided definitions of logistics systems, it can be stated that the majority of authors have similar views on their features:

1) They are social and economic systems;

2) Have a certain structure, described by a set of network and administration system;

3) Are created for the management of material flows and their attendant once.

Table 1. Definitions of logistics systems in the literature sources (fragment)

\begin{tabular}{|c|c|}
\hline Source & Definition \\
\hline $\begin{array}{l}\text { (Grigoriev et al., } \\
2006)\end{array}$ & $\begin{array}{l}\text { Logistics system is an ordered structure, in which the planning and implementation of } \\
\text { motion and development of aggregate resource potential, are organized in the form of } \\
\text { logistics flow starting from the alienation of resources from the environment up to the } \\
\text { realization of the final output }\end{array}$ \\
\hline (Sergeev, 1997) & $\begin{array}{l}\text { Logistics system is a complex organizationally completed (structured) economic } \\
\text { system consisting of flows of elements interconnected in a single management process } \\
\text { of material and their attendant-links, whose aggregate, boundaries and functioning } \\
\text { objectives are connected by the internal business organization objectives and/or } \\
\text { external goals. }\end{array}$ \\
\hline $\begin{array}{l}\text { (Dybskaya et al., } \\
2008)\end{array}$ & $\begin{array}{l}\text { Logistics system is a set of logistics network and administration system, formed by a } \\
\text { company to implement its logistics strategy. }\end{array}$ \\
\hline
\end{tabular}

As far as social and economic categories are concerned, logistics systems and, hence, storage systems are characterized by the following:

- Non-stationarity (volatility) of individual system's parameters and stochastic behaviour;

- Uniqueness and the probabilistic nature of the system's behaviour under specific conditions;

- The ability to change its structure, while maintaining the integrity, and shape behaviours (which is also caused by the availability of active elements);

- Ability to resist entropic (depleting the system) tendencies;

- Ability to adapt to changing conditions;

- Ability and striving for goal formation, etc. (Budrina et al., 2006).

Represented general characteristics of storage systems require reflection in the appropriate methodology of 
managing such systems. However, the available scientific literature on logistics and supply chain management, including storage logistics, presents the provisions of the methodology only in fragments, in terms of individual management functions. In particular, the papers (Dybskaya, 2000, 2005, 2008, 2009) cover the design of storage systems; the authors (Kuzmina, 2000; Lyabakh \& Butakova, 2004; Kireyeva, 2009) thoroughly developed the problematics of operative storage business, the monograph (Sergeev, 1997) outlines the principles of logistics systems based on logistics integration, fully applicable to the considered object of study.

Moreover, complex elaboration of methodological basis for storage systems management is systematically linking results of the study of concept and categorical apparatus of logistics storage, management principles, and science-based sequence of solving logistics storage problems for different levels of storage systems management are missing.

\section{Method}

The transformation of the essential characteristics of the methodology presented by the authors (Novikov, Novikov, 2007) and their proposed procedures of its development in relation to storage systems, gives the possibility to state that hence the methodology is considered as the study of the organization of activities and management in general including the management of storage systems as a kind of practical activities respectively it can be arranged in accordance with the common factors including the definition and description of: a) the characteristics; b) the logical structure; c) the temporary structure of this type of activity.

The relation of the concepts such as "logical structure" and "characteristics of the activities" shall be clarified.

The logical structure means the sum of subject, object, subject matter, shape, means, methods of the operations, and its result.

The activity characteristics are external to the logical structure and include features, principles, conditions, and standards of activity.

The process of forming the activity temporal pattern is based on the technological and design type of activity organization that is common to a modern type of the organisational culture (Nikitin, 1998). This approach involves activity partitioning in the individual cycles, the completion of which is determined by the following phases: 1) planning, 2) processing, and 3) reflexive with further detailing to the level of stages and phases.

It is important to note that in the process of forming the methodology, the development of its individual components does not take place sequentially. For example, the development of the logical structure of an activity almost completely coincides with the first phase of the temporal structure - the design phases since the construction of the system presupposes its detailed presentation. For this reason, during the description of the formed methodology of storage management systems will rely on the temporal structure of the activity, which allows, firstly, preserving the logical sequence of formulating and solving the problems connected with the storage management systems; secondly, avoiding duplication in the process of the description for individual blocks.

Solving the control problems is impossible without a comprehensive understanding of the control object. So the main task of the design phase is the study of the characteristics and the development of a model-driven storage system. In this way, this phase coincides with the formation of the logical structure, which is involved in the developed methodology. The following stages are included in this phase:

- Conceptual stage. At this stage based on the formed characteristics of the controlled system a goal and objectives of the system are formulated selecting the criteria;

- Modelling stage. This phase is based on the construction, analysis, and optimization of the models for the researched system;

- Designing stage. In general, the work at this stage involves determining of the specific ways and means for implementing the model. With regard to the storage systems as the ways and means it is seemed to consider the developed models, methods, techniques and algorithms of formation of storage systems and their individual components.

The most important methodological aspect of the phase under consideration is its close relation to the concretization of the characteristics for the controlled object, which, in turn, requires fulfilling of the following tasks:

1) Clarification of concepts, properties, and characteristic features of the storage systems;

2) Structural and functional description of the storage systems and their elements with the subsequent formation 
of targets and sub-targets for different levels of the storage system.

\section{Results}

\subsection{Development of Conceptual Models' Complex of Storage Systems and Their Individual Elements}

The proposed solution for the problem of structural and functional description of the storage systems and their elements with the subsequent formation of targets and sub-targets for different levels of storage system is based on the results of the studies presented in the papers by (Budrina et. al., 2006; Sergeev, 1997). Taking into account the arguments in the above mentioned sources, it shall be noted that regarding the terminology of logistics, the terminology of the storing the storage system is characterized by the storage management system of the company and by the parameters of the storage network. The latter, in turn, includes the following elements of the next lower level - storage facilities of various types defined, in the first place, by their functions in the logistics system.

From there, the developed graphical conceptual model of the storage system as a part of an integrated micro-logistical socio-economic system is presented in the form of enlarged diagram in Figure 1, and allows as follows: first, specification of the understanding of the storage systems structures; second, formulation of the basic management objectives for the different levels of storage systems. Thus, the hierarchy of management objectives includes the following:

1) At level of storage system - the efficiency for improving of the logistics system functioning;

2) At storage network - the formation of economic and service benefits in the logistics system;

3) At level of storage - the transformation of cargo flows parameters in accordance with the requirements of the ultimate consumers or conditions of subsequent efficient transportation.

The following specification of the developed model requires the detailing of storage belonging to the functional logistics, i.e. specification of its functional purpose in the logistics system, which, in turn, determines the purpose, functions, tasks, performance criteria of the functioning of the storage as a storage system echelon (SSE). The study of storage facilities of various functional purposes, presented to them by the logistic system requirements, allowed specification of the local goals and objectives of different types of storages, as well as integrated control sub-system (Table 2), which are further used in the selection of the necessary methodological support at later levels of the developed methodology.

Let us consider another aspect, which clarifies the characteristics of storage systems. According to those mentioned above, and in the course of scientific debate, the possibility of submitting a separate storage facility as a logistics system was concluded. Indeed, the further decomposition of the storage as an echelon of the logistics system of higher level allowed identification of the characteristics for micro-logistics system (graphical representation is shown in Figure 2).

The diagram (Figure 2) uses the approach to classification of logistics flows, proposed by the author (Odintsov, 2011).

The most productively, the presented model can be used in describing of the operation of storage logistics intermediaries. An important feature of this storage type is a feature of goal setting and selection of the main tasks for their functioning. Thus, the main purpose for this category is the traditional storage performance indicators of businesses (profit margin, performance indicator based on cost-based approach). In this case, the target selection is made independently and is not given from the "outside" for its own storages in the companies. Thus, the main problem is reduced to the most efficient usage of the available resources.

\subsection{The Structure of the Methodology of Storage Management Systems}

Presentation of the storage system as the main part of the higher level logistics system, on the one hand, and the storage as a micro-logistics system, on the other hand, allows formulating of methodological principles for design and analysis of such systems; as well as the goals and objectives of warehousing logistics for various levels of management. In addition, it allows rational choice of analytical tools to solve them depending on the level of the logistics system development and the maturity of logistics integration process (the design stage). 


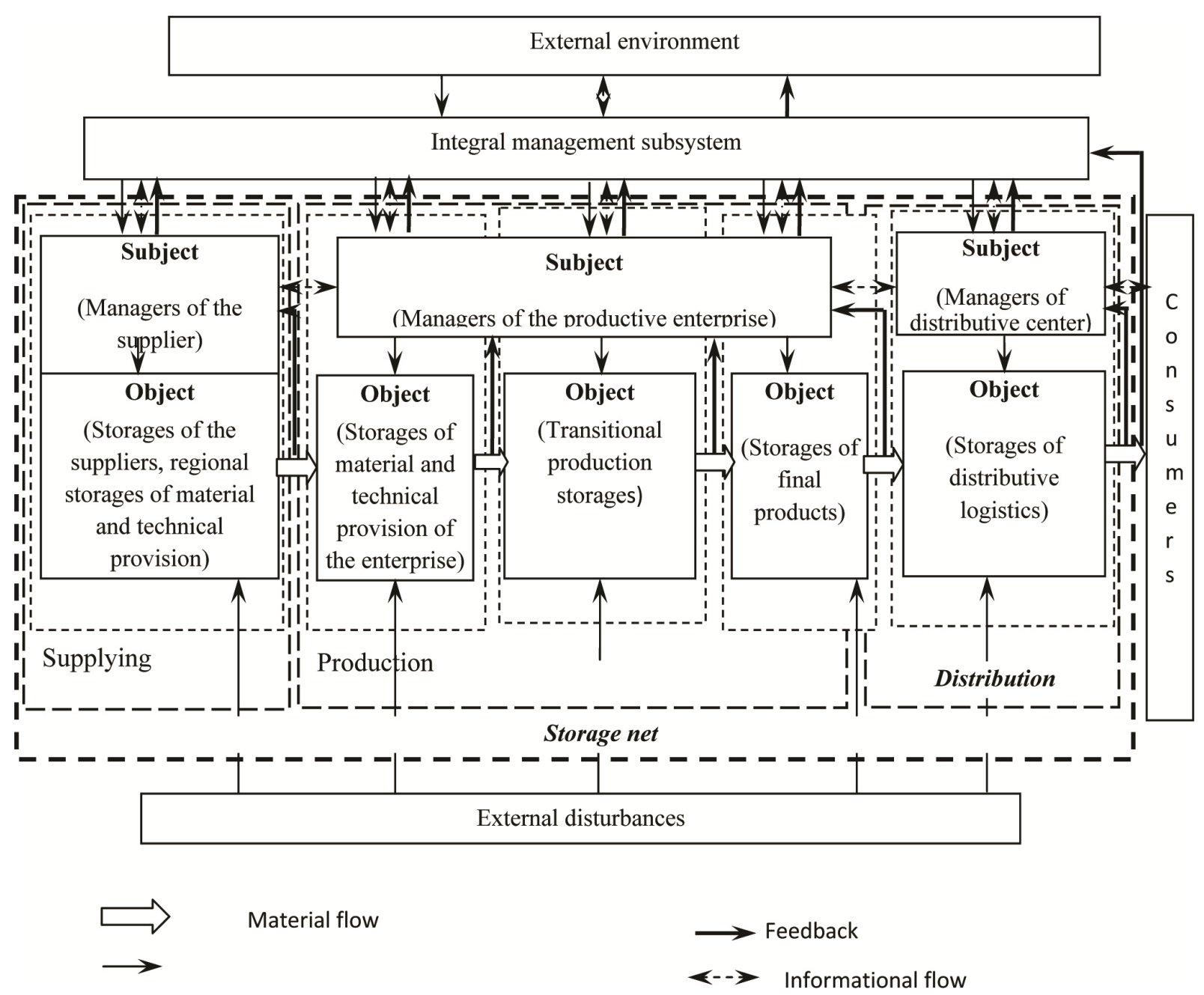

Figure 1. The integrated diagram of the storage system as a part of micro-logistics integrated system

Table 2. Goals and objectives of storage system echelons in various functional areas of logistics

\begin{tabular}{llll}
\hline $\begin{array}{l}\text { Element } \\
\text { storage system }\end{array}$ & of & $\begin{array}{l}\text { Functional sphere of } \\
\text { logistics }\end{array}$ & Goals, objectives \\
\hline
\end{tabular}

Integral All functional spheres Goal: Integrated management of logistics functions and operations of
management promoting material flow through the storage system

subsystem

Tasks at the macro-level:

- Configuring network storage company depending on the requirements of the corporate strategy, the chosen concept of inventory management and other factors;

- Determining the optimal number of storage objects in the storage system;

- Determining the optimal space arrangement of the storage facilities;

- Choosing the form of ownership of individual units in the storage system

Tasks at the micro-level:

- Developing the control actions in response to the changing environmental conditions;

- Coordinating the various echelons of the storage system 


\begin{tabular}{|c|c|c|}
\hline \multirow[t]{4}{*}{$\mathrm{SSE}_{1}$} & Supplying & $\begin{array}{l}\text { Goal: Reducing the total costs for the promotion of material flow by } \\
\text { ensuring the highest possible functional integration with the transport } \\
\text { logistic function }\end{array}$ \\
\hline & & Objectives: \\
\hline & & $\begin{array}{l}\text { - Unitising consignment of goods in accordance with the carrying } \\
\text { capacity (tonnage) of the main means of transport; }\end{array}$ \\
\hline & & - Detailed design of the process storage areas in the storage facility \\
\hline \multirow[t]{5}{*}{$\mathrm{SSE}_{2}$} & Supplying-Production & $\begin{array}{l}\text { Goal: Meeting the needs of the production of the necessary resources } \\
\text { with a given level of reliability }\end{array}$ \\
\hline & & Objectives: \\
\hline & & $\begin{array}{l}\text { - Developing the strategies of supplying depots with the material } \\
\text { resources in accordance with the selected production concept; }\end{array}$ \\
\hline & & - Designing and implementing integrated production storage systems; \\
\hline & & $\begin{array}{l}\text { - Forming the basic modules of orders in accordance with the needs of } \\
\text { the production process }\end{array}$ \\
\hline \multirow[t]{4}{*}{$\mathrm{SSE}_{3}$} & Production & $\begin{array}{l}\text { Goal: Converting traffic parameters in accordance with the } \\
\text { requirements of the production process }\end{array}$ \\
\hline & & Objectives: \\
\hline & & $\begin{array}{l}\text { - Algorithmising and formalising the basic parameters of } \\
\text { technological operations in the storage; }\end{array}$ \\
\hline & & - Automating storage technological process \\
\hline \multirow[t]{5}{*}{$\mathrm{SSE}_{4}$} & $\begin{array}{l}\text { Production-Distributi } \\
\text { on }\end{array}$ & $\begin{array}{l}\text { Goal: Converting of the mix of products in the consumer range } \\
\text { depending on the market demand }\end{array}$ \\
\hline & & Objectives: \\
\hline & & $\begin{array}{l}\text { - Organising the effective service with the wide variety of options } \\
\text { contracts; }\end{array}$ \\
\hline & & - Detailed design of flexible storage systems; \\
\hline & & $\begin{array}{l}\text { - Organising the reception of products in accordance with the } \\
\text { parameters of the production process }\end{array}$ \\
\hline \multirow[t]{6}{*}{$\mathrm{SSE}_{5}$} & Distribution & $\begin{array}{l}\text { Goal: Meeting the requirements of ultimate consumers with a given } \\
\text { level of service }\end{array}$ \\
\hline & & Objectives: \\
\hline & & - Reducing the time of the basic cycle distribution; \\
\hline & & $\begin{array}{l}\text { - Designing and promoting organization of material flow by using } \\
\text { cross-docking technologies; }\end{array}$ \\
\hline & & - Controlling the conditions of the "perfect order"; \\
\hline & & - Forming effective systems of picking of customer orders \\
\hline
\end{tabular}

It shall be noted that the complex of models and methods, making up the necessary framework of methodology to solve the tasks at the design stage according to formed methodology, is developed with some details as is evidenced by the results of the carried out systematisation of modern scientific and methodological support of the storage systems forming task. We believe, that in this regard, it is necessary to confine by means of researching, the directions of further development of methodological support used in solving the problems of storage systems design.

The first direction is the solution to the problem of choosing the configuration of the network storage.

It is easy to notice that the problem of functional integration of transportation and storage is realized mainly at the micro-level control while the integration of warehousing and inventory management is a prerogative at 
mainly macro-level and, in relation to logistics warehousing, it is manifested in features of configuration of the storage network. As noted by (Lukinskiy et al., 2011), the subsequent development of the theoretical section of logistics, consideration of the logistics system shall be based on the principles of differentiated approach to the study of logistics systems the formation of which is a preliminary classification.

However, the analysis of classification schemes of high-level objects (here we are talking about a storage network) is difficult, hence the author failed tp find a detailed description of the structural varieties of storage networks in the available sources, the selection of which is based on various supply models (direct delivery, positioning on the line, plane, transport network). Indeed, these models allow focusing on the criterion of total logistics costs. However, it shall be remembered that one of the main functions of warehousing in the logistics system is to store various types of stocks. Therefore, in our opinion, the decision concerning the choice of configuration storage network shall be closely linked with the strategy of inventory management in the logistics system and rely on the classification of logistics systems based on the location of the reserves.

Further study of the functioning features of different types of storage facilities based on refinement of parameters of cargo passing through the storage, features and characteristics of the occurring processes determines the content of the second direction of development of methodological supportive design and storage management systems.

The researches allowed structuring, as follows, the basic steps and stages of design phase of the developed methodology.

One of the urgent problems of the real functioning of storage systems in Russia is the presence of time loss in the storage network centres and, therefore, slowed rate of material flow, which, in turn, leads to lower quality of ultimate consumer service. A major factor in the emergence of this situation is a mismatch of service systems of logistical chain and the parameters of the incoming material flow and a direct consequence of the mistakes made during the design phase. Meanwhile, such a discrepancy is also due to the insufficient development of the methodological support of storage management systems, which do not fully take into account the requirements of the modern conditions of their operation. Solving these problems is provided on the technological phase of the temporal structure.

Description of the technological phase generally is quite difficult, since even in the sphere of production, a single doctrine of the technology does not exist. Common approaches to the description of technologies, common principles, and rules of their construction have not been developed even now. The choice of used technology is determined by the content of a particular activity. However, based on a universal definition of technology, according to which the technology is viewed as a "system of conditions, forms, methods and means of solving the problems" (Novikov \& Novikov, 2007), it can be concluded that the central concept in this case is the problem and goal (sub-goal), given under specific conditions. 


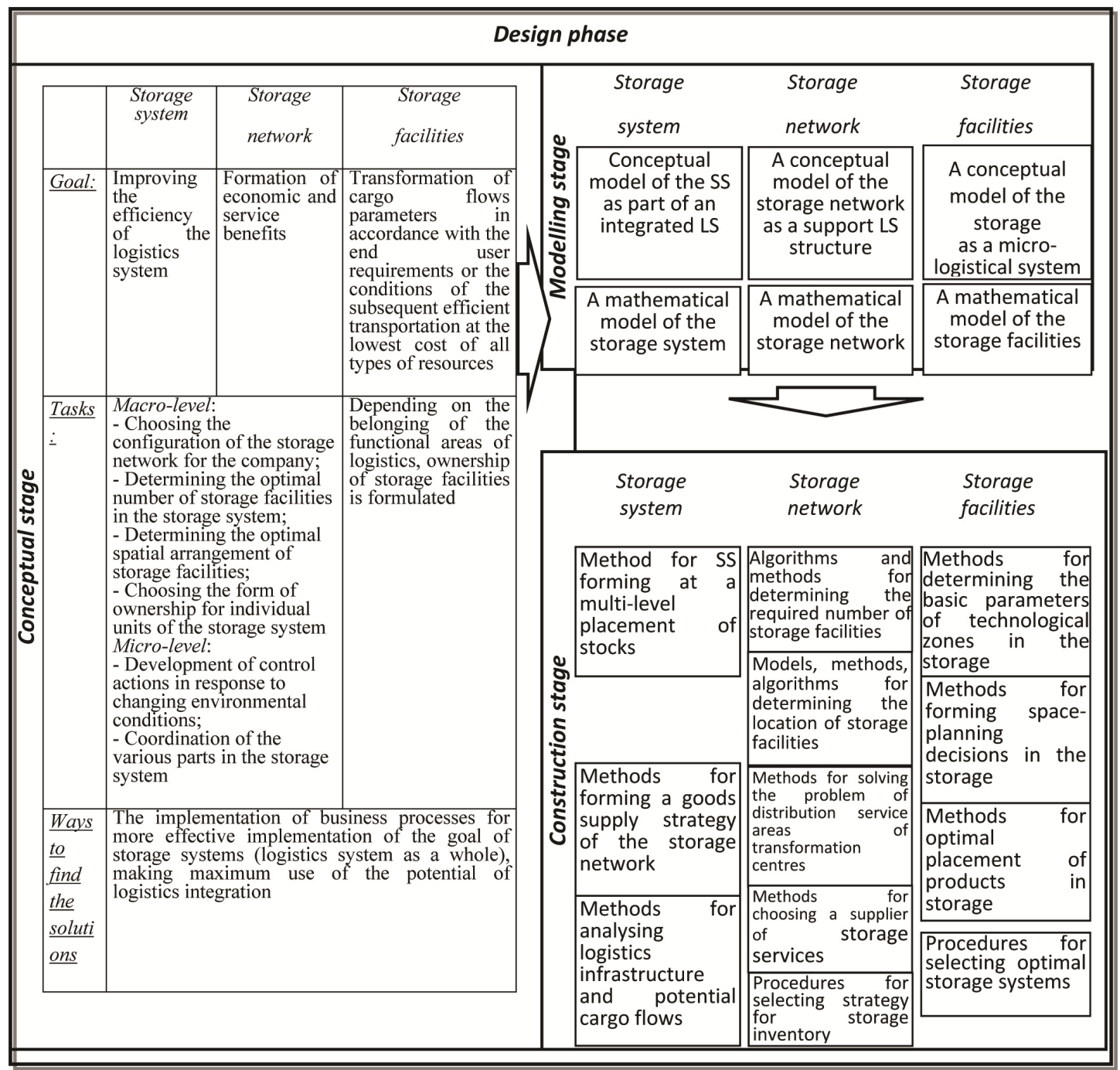

Figure 2. Structure of the design phase for the methodology of storage management systems

The dependence of the storage system efficiency from the control actions, for search of which a developed model system is used, is the management efficiency factor. In this case, the task of managing storage system can be formulated as the task of finding the admissible control actions with the greatest efficiency.

Thus, the process phase includes definition of the main objectives and performance criteria storage management system, formulation of local tasks (tasks at the storage level), as well as methodological support for their decisions.

Reflective phase assesses the progress in the implementation of previous phases. Such assessment is performed using one or few methods for evaluating the logistics system effectiveness. Detailed structure of technological and reflexive phases is shown in Figure 3.

The general scheme of methodology for storage system management is presented in Figure 4.

\section{Discussion}

Presently, functioning of storage system and storage units, being the elements of logistics (socioeconomic, as well) system, on the one hand, and complex technical and technological objects and systems, on the other hand, as was mentioned in the papers by (Dybskaya, 2009; Dybskaya et al., 2008, Malikov, 2005; Pustobayev, 2007, etc.), is closely related to the necessity of solving complex of management tasks posing the following features:

- High rate of uncertainty often occurring due to the lack of priori information about structure, parameters, and functions of storage as an object of research (in particular, to solve the problem of designing a new storage facility); 
- Complex system structure providing simultaneous and multi-phase work (support);

- Non-stationarity, nonlinearity, and randomness of the process;

- High information load of the system elements;

- Necessity of taking a decision in real time;

- Necessity of local (little dependence on external environment and subject) functioning, etc. (Lyabach \& Butakova, 2004).

The proposed methodology of storage system management, systematizing and developing the theoretical and methodological studies, presented in the modern scientific literature on logistics, defines the macro process in logistics warehousing management. It allows consideration of a range of problems emerging in storage management systems with account for the results of studying a real-world performance of such systems.

\section{Conclusion}

The developed methodology of storage system management provides an opportunity to adjust methodical support for logistic functions of storing, transportation, and inventory management, to ensure rational management decisions based on identified and described properties of storage systems and actual mechanism of implementing individual logistics functions in the supply chain.

In our opinion, at the present stage of the development of storage systems, the most urgent task is the task of technological phases of methodology, which relates to the formation of management decisions based on the most important modern requirements for storage systems, namely:

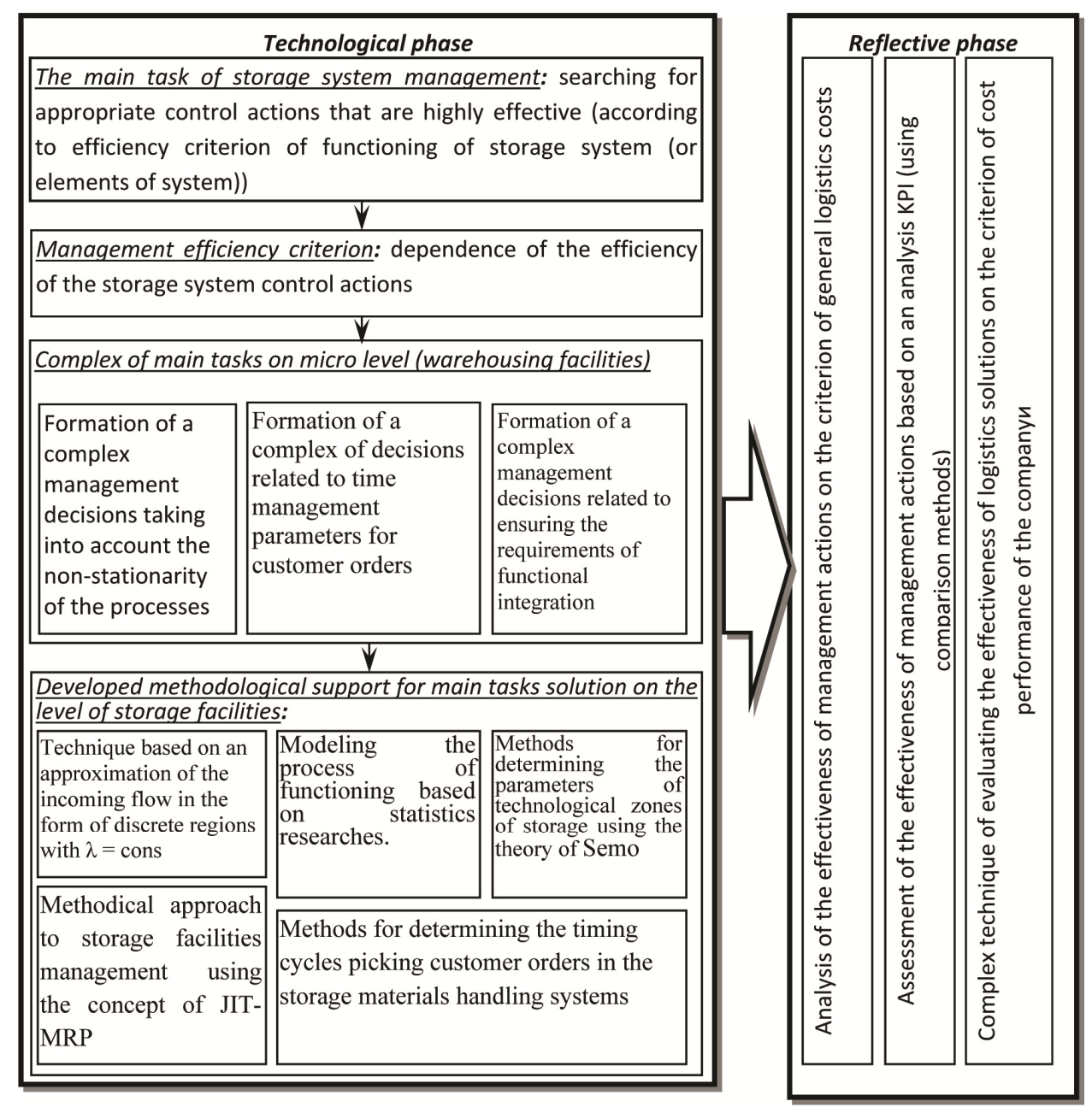

Figure 3. Structure of technological and reflective phase methodology of storage management systems 
a) Non-stationarity occurring in storage systems (and in logistics systems in general) processes;

b) Improving of the timing requirements for the components of the logistics cycle;

c) The need to formalize the functional integration approaches.

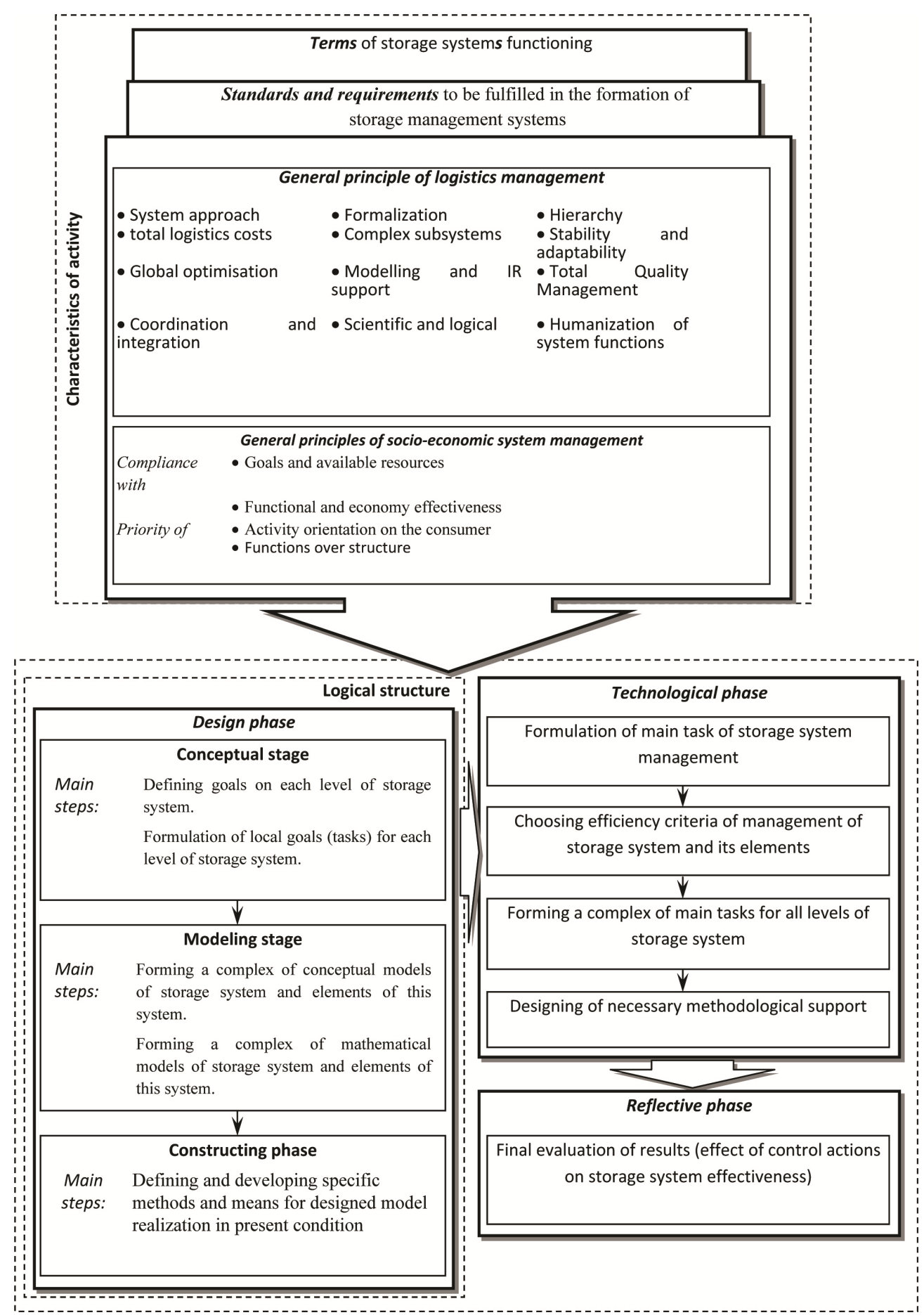

Figure 4. The general scheme of the warehouse management systems methodology 


\section{References}

Budrina, E. V., Lukinskii, V. S., \& Schislyaeva, E. R. (2006). Logisticheskie metody i modeli upravleniya kadrami $v$ usloviyakh usileniya kul'turnykh $i$ global'nykh tendentsii $v$ mezhdunarodnom biznese: Monografiya (p. 166). Saint Petersburg: Izd-voPolitekhn. un-ta.

Ditrikh, M. (2004). Skladskayalogistika. In Novyeputisistemnogoplanirovaniya (p. 136). M.: KIA tsentr.

Dorodnikov, V. N., \& Malashenko, N. P. (2001). Skladskoekhozyaistvo (p. 79). Novosibirsk: NGAEiU.

Dybskaya, $\quad$ V. $\quad$ V. $\quad$ (2000). Logisticheskayaorganizatsiya $i$ upravlenieskladirovaniemnapriedpriyatiyakhoptovoitorgovli (p. 32). SaintPetersburg: Izdatel'stvoSPbGUEF.

Dybskaya, V. V. (2008). Metodologiya resheniya problem logistiki i skladirovaniya. Logistika i upravlenie tsepyami postavok, 1(24).

Dybskaya, V. V. (2009). Upravlenie skladirovaniem v tsepyakh postavok (p. 720). M.: Izdatel'stvo “Al'fa-Press".

Dybskaya, V. V., Zaitsev, E. I., Sergeev, V. I., \& Sterligova, A. N. (2008). Logistika: Uchebnik (p. 944). Moscow: Eksmo.

Emmett, S. (2007). Excellence in Storage Management: How to Minimise Costs and Maximise Value. Grevcov Publisher.

Fugate, B. S., Mentzer, J. T., \& Stank, T. P. (2010). Logistics Performance: Efficiency, Effectiveness, and $\begin{array}{lllll}\text { Differentiation. Journal of Business } & \text { Logistics, }\end{array}$ http://dx.doi.org/10.1002/j.2158-1592.2010.tb00127.x

Grigor'ev, M. N., Dolgov, A. P., \& Uvarov, S. A. (2006). Logistika: Uchebnoe posobie dlya studentov vuzov (p. 463). Moscow: Gardariki.

Hompel, T. (2003). Storage Management.

Kireeva, N. S. (2009). Skladskoe khozyaistvo: Ucheb. Posobie (p. 192). M.: Izdatel'skiitsentr “Akademiya”.

Kurganov, V. M. (2009). Logistika. Transport i sklad v tsepi postavoktovarov: Uchebnoe prakticheskoe posobie (p. 512). Moscow: Knizhnyimir.

Kuz'mina, T. S. (2000). Skladskoe khozyaistvo v logisticheskoi sisteme: Uchebnoe prakticheskoe posobie (p. 69). Volgograd: Volgograd State University Publisher.

Lukinskogo, V. S. (2011). Teoreticheskie i metodologicheskie problemy upravleniya logisticheskimi protsessami $v$ tsepyakh postavok (p. 242). Saint Petersburg.

Lukinskogo, V. S., \& Badokin, O. V. (2011). Upravlenie zapasami v tsepyakh postavok: Ucheb. Posobie (p. 287). Saint Petersburg.

Lyabakh, N. N., \& Butakova, M. A. (2004). Sistemy massovogo obsluzhivaniya: Razvitie teorii, metodologiya modelirovaniya i sinteza: Monografiya (p. 200). Rostov-on-Don: Rostov State Transport University.

Pashkov, A. K., \& Polyarin,Yu. N. (2003). Skladskoe khozyaistvo i skladskie raboty (p. 365). Moscow: Akademkniga.

\section{Copyrights}

Copyright for this article is retained by the author(s), with first publication rights granted to the journal.

This is an open-access article distributed under the terms and conditions of the Creative Commons Attribution license (http://creativecommons.org/licenses/by/3.0/). 